\title{
An overview of the Portuguese wind power sector
}

\author{
Paula Ferreira \\ Department of Production and Systems, University of Minho, Portugal \\ paulaf@dps.uminho.pt \\ Madalena Araújo \\ Department of Production and Systems, University of Minho, Portugal \\ mmaraujo@dps.uminho.pt \\ M.E.J. O’Kelly \\ EIRGRID, plc, Ireland.
}

\begin{abstract}
In the following paper the present situation of the electricity production from Renewable energy Sources (RES) in Portugal is analysed, giving particular attention to the wind power sector due to its increasing importance. The evolution of the electricity system is presented along with the strategies for the sector, and future prospects for the RES. Although the high interest of private companies in the wind sector the administrative and grid barriers represent major obstacles to the wind power development. The problem of the wind intermittency and uncertainty is also discussed. The improvement of interconnection capacity and the increase of power reserve are identified as key requirements for ensuring the security of supply. A clear comprehension of all these aspects is fundamental to aim for an integrated multidimensional wind power planning.
\end{abstract}

\section{Keywords}

Renewable energy sources, wind power, electricity generation. 


\section{Introduction}

In 1996, the European Commission published the Green Paper on renewable sources of energy, where it pointed the need to attain a significantly higher share of renewable energy in the European energy balance (European Commission, 1996). The following White Paper (European Commission, 1997) established a comprehensive strategy and an action plan for the reinforcement of the renewable energy production. In September 2001, the European Commission published Directive 2001/77/EC for the promotion of electricity from renewable energy sources, stressing their contribution to environmental protection, sustainable development, security of supply and the Kyoto targets. In this document, a global indicative target was set, $12 \%$ of gross domestic energy consumption by 2010 produced from renewable sources. It also sets National indicative targets for each EU country, consistent with the global indicative target and in particular with the $22.1 \%$ share of electricity produced by RES in total Community consumption, by 2010 (Article 3).

As for Portugal, the share of electricity produced by RES was in 1997 about 38.5\% of the gross electricity consumption. The directive sets a target of 39\% in 2010, due to the expected growth of the electricity consumption for the following years. This target assumes for Portugal that (Directive 2001/77 /EC, annex):

“- it will be possible to continue the national electricity plan, building new hydro capacity higher than $10 \mathrm{MW}$,

— other renewable capacity, only possible with financial state aid, will increase at an annual rate eight times higher than has occurred recently. 
These assumptions imply that new capacity for producing electricity from renewable sources, excluding large hydro, will increase at a rate twice as high as the rate of increase of gross national electricity consumption.”

The Portuguese government bases its policy for the energy sector in three strategic points: Assuring the security of supply, stimulating the sustainable development and promoting National competitiveness ${ }^{1}$.

Portugal is strongly dependent on external energy sources, in particular oil. In 2004, $86 \%$ of the primary energy came from imports, and oil represented about $58 \%$ of the primary energy consumed (DGGE, 2005a). The only National resources came from the renewable energy sources, specially the hydro sector for electricity production. This way, the renewable energy sector has a fundamental role for the reduction of the external energy dependence, actively contributing to increase the security of supply.

From the environmental point of view, the promotion of renewable energy sources contributes to the reduction of several undesired outcomes such as greenhouse gases and fossil fuel consumption and to the collection and treatment of residuals (BCG, 2004). According to the 2005 submission for the UN Framework Convention on Climate Change, in 2003, 90\% of the $\mathrm{CO}_{2}$ emissions in Portugal came from the energy usage, and $27 \%$ of National $\mathrm{CO}_{2}$ emissions were due to the public electricity and heat production $^{2}$. The emissions of the public electricity and heat production were only overcame by the transport sector, making clear the need to develop a new energetic system based on low carbon emissions.

\footnotetext{
${ }^{1}$ Resolution of the Council of Ministries 63/2003.

${ }^{2}$ www.iambiente.pt
} 
The development of the renewable energy sector represents an important contribution also to the National competitiveness, reducing the risk associated with the fuel price volatility, creating new investment opportunities and additional employment. The BCG (2004) report calls attention to the possibility of expanding the RES equipment National industries, incorporating these equipments in National projects or exploring the possibility of exports.

The wind power sector is essential for the concretization of the European renewable objectives. According to the EU forecasts the large hydropower will mantain its dominant position on RES for the near future. However, wind energy will continue expanding and in 2025 the wind capacity will overcome the hydro sector in the EU-25 (European Commission, 2004a). During the period 1996 to 2004, the global wind power installed increased from 6,070 MW to 47,007 MW. In the EU-25, the total installed capacity reached 34,366 MW, mostly concentrated in Germany, Spain and Denmark (EWEA, Greenpeace, 2005; EuroObserv'ER, 2005). According to the EWEA forecasts, it is feasible for wind power to supply $12 \%$ of world's electricity demand by 2020 (EWEA, Greenpeace, 2005).

Portugal is no exception and the wind sector is growing rapidly. The National objectives for energy include a significant increase of wind power during the next years. If the drawn objectives are accomplished, by 2010 the wind power share may reach values comparable to the present Danish situation and higher than in Germany or Spain.

The focus of this paper is to analyse the present situation of the electricity production from RES in Portugal, giving particular attention to the wind power sector due to its 
increasing importance. The evolution of the the Portuguese electricity generating system over the years is examined, along with the legal and political environment, presenting also the future prospects of the sector.

The next section describes briefly the Portuguese electricity system ${ }^{3}$, the state of the RES and some forecasts. In the third section the legal and political environment of the renewable energy sector are outlined, as well as its evolution and present situation. In the fourth section, an analysis of the Portuguese wind energy sector in the European context is presented pointing the main problems and future prospects. The fifth section reviews some recent works on energy planning and proposes an approach to a planning tool for wind power. The main conclusions are summarised at the end.

\section{Portuguese electricity system}

The Portuguese electricity generating system is a mixed hydrothermal system. The total installed power reached in 2005 about 12,758 MW, distributed between thermal power plants (coal, fuel oil, natural gas and gas oil), hydro power plants and Special Regime Producers (SRP- renewable plants and cogeneration), as presented in Table 1.

Table 1- Distribution of installed power and electricity production in mainland Portugal, 2005. Source: (REN, 2005a).

\begin{tabular}{lcc}
\hline & Installed power (MW) & Electricity production (GWh) \\
\hline Thermal power plants & 5,851 & 30,598 \\
Large hydro power plants & 4,582 & 4,539 \\
Special regime producers & 2,325 & 6,563 \\
Total & 12,758 & 4,669 \\
\hline
\end{tabular}

\footnotetext{
${ }^{3}$ The study does not include Azores and Madeira islands.
} 
The REN (2005b) forecasts predict a 41\% increase of the total installed power between 2006 and 2011, and an additional 24\% increase until 2016. Figure 1 shows the distribution of the total installed power in 2005 and the forecasts for the following years.
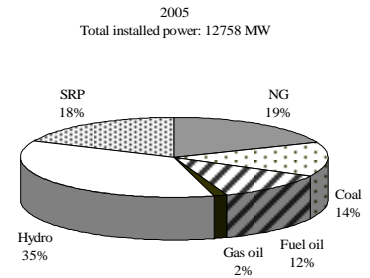
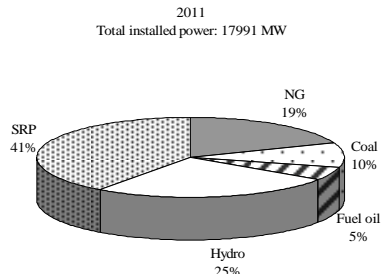

Total installed power: $22289 \mathrm{MW}$

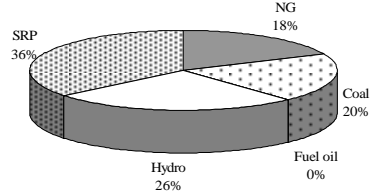

Figure 1- Total installed power in 2005 and forecasts for 2011 and 2016. Source: Own elaboration from REN(2005a); REN(2005b).

According to these forecasts there will be a reduction of the thermal and large hydro quote and a large increase of the SRP quote. All the energy sources will growth in absolute terms, with the exception of gas and fuel oil due to the desactivation of the power plants presently consuming it. The thermal power will increase exclusively due to the growth of the natural gas power groups until 2013. After that, the REN (2005b) scenarios assume new investments both in coal and natural gas. The growth of the SRP will be mostly due to the increase of the renewable energy sector, in particular wind. According to these scenarios, in 2011, the wind sector will achieve about $25 \%$ of the total installed power.

The future of the electrical power systems is strongly constrained by international environmental agreements, namely the Kyoto protocol and RES Directive. The Portuguese strategy for the electrical system, based on RES and natural gas growth, is fundamental to accomplish these goals. 
The evolution of the hydroelectric sector along with the SRP is part of the Portuguese strategy for the electrical system, representing a clear effort for the promotion of endogenous resources, reduction of external dependence and diversification of consumptions. The combined growth of natural gas and coal allows, also for the reduction of Portuguese strong oil dependence, contributing for the diversification of primary energy sources.

Figure 2 presents the evolution of electricity production from renewable energy sources in Portugal (excluding islands). As it may be seen, the hydro generated electricity is the most important RES, with a contribution of 54\% of the total RES production in 2005. Biomass power production with a $22 \%$ share, wind with $20 \%$ and small-scale hydro with 3\% followed it. Thus, the total RES production is extremely vulnerable to the hydro conditions. Between 1997 and 2003, the total large hydropower installed remained unchanged; however its total production suffered strong variations. Dry years like 1999, 2002 and 2005 led to small RES production, whereas wet years like 2003 led to large RES production. Between 2003 and 2005, the installed large hydropower grew more than $10 \%$, however its production in 2005 (an extremely dry year) was reduced in almost 70\% in relation to 2003. 


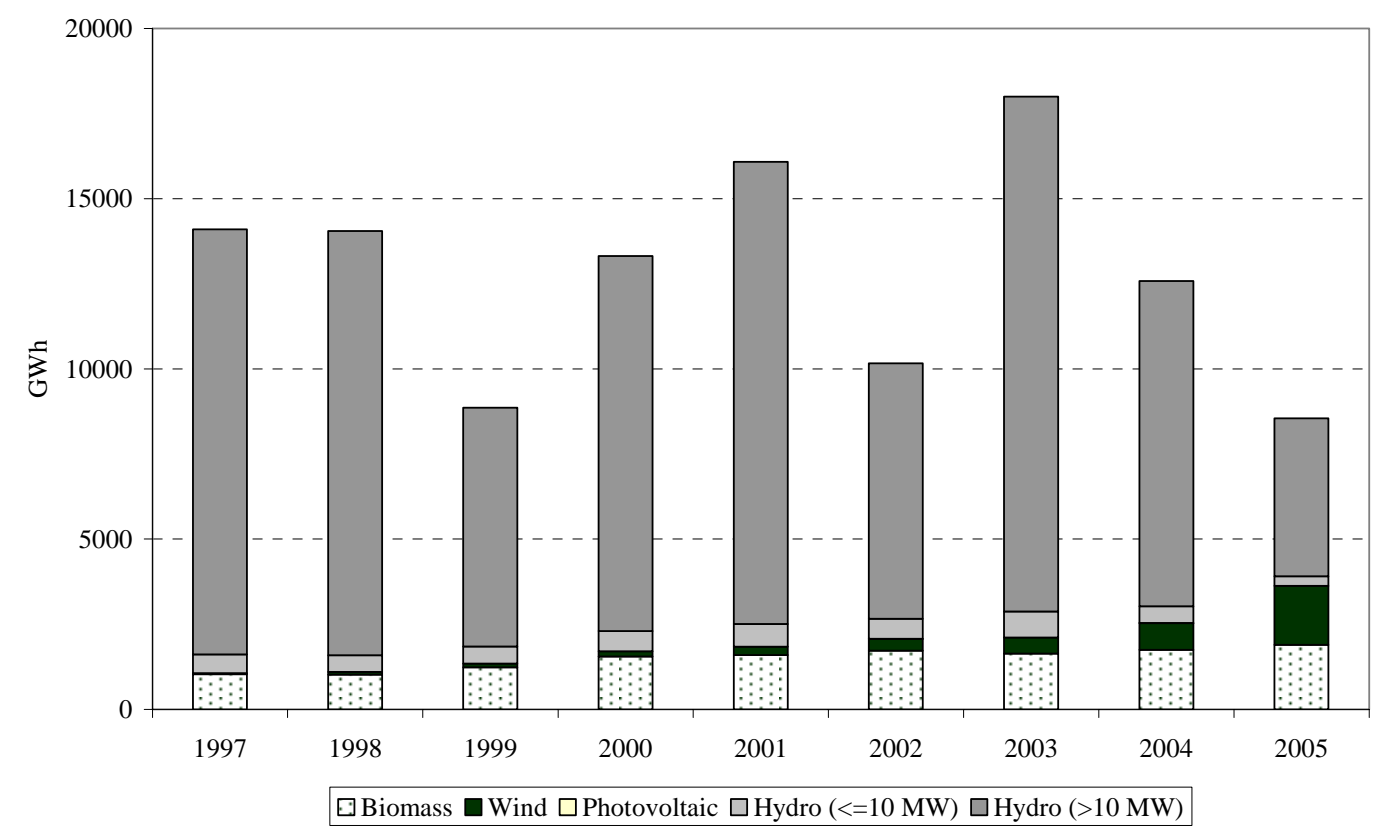

Figure 2- Electricity production from RES in Portugal (excluding islands), 1997-2005. Source: Own elaboration from DGGE (2005b).

The strong role of the hydropower production in Portugal becomes evident by analysing the distribution of the electricity production between hydro, thermal and renewable energy sources. Figure 3 presents this distribution between 1997 and 2005 for mainland Portugal, and indicates the Hydraulic Productivity Index (HPI) for each year. 


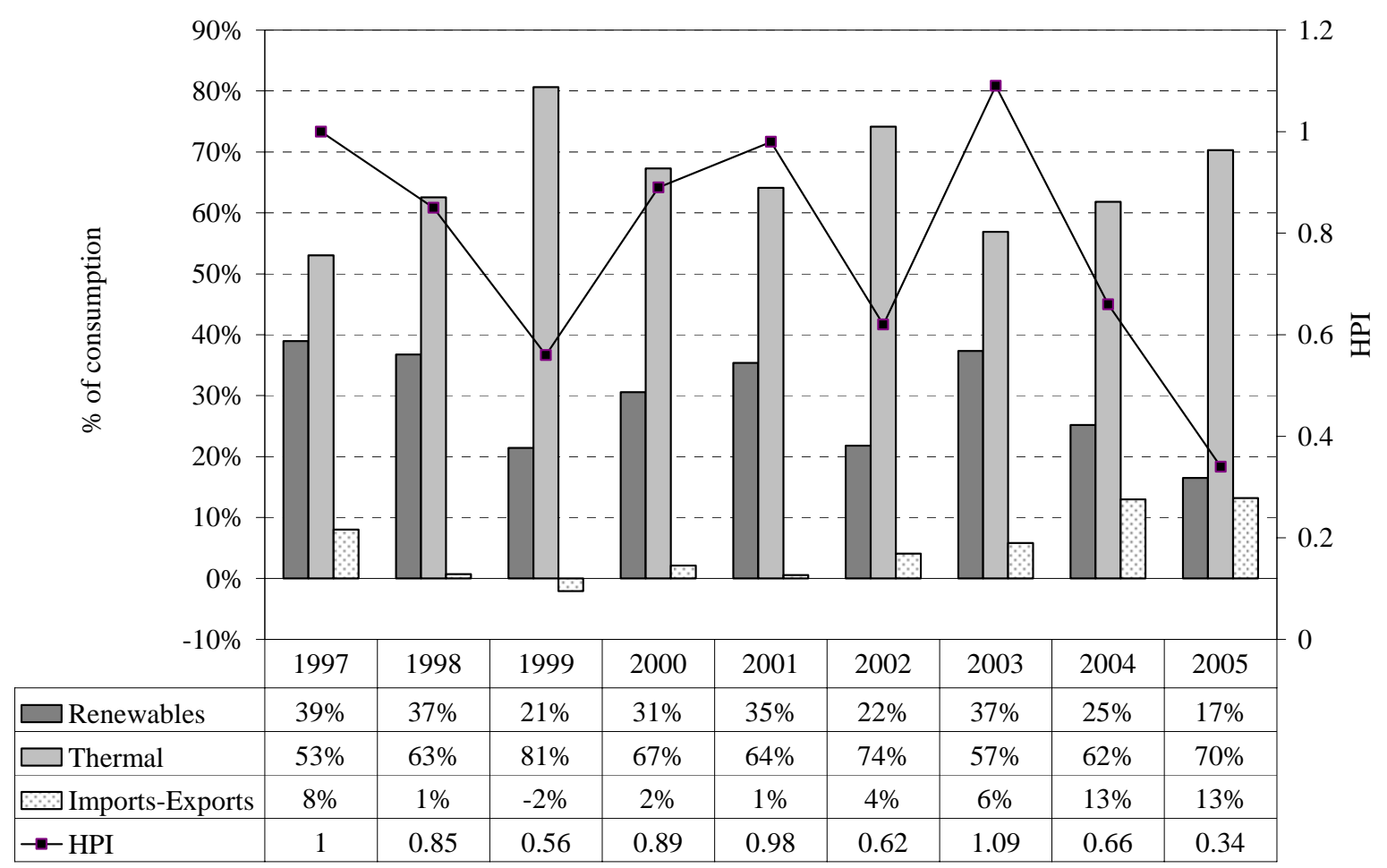

Figure 3- Thermal and hydro electricity production, electricity changes with abroad and HPI in Portugal (excluding islands), 1997-2005. Source: Own elaboration from DGGE (2005b).

In 1999, the thermal power production represented more than $80 \%$ of the total electricity consumption. This was the year with a most modest HPI, leading to a reduced share of electricity produced from RES. The same happened in 2002, however the reduced hydro production was compensated not only by the thermal sector but also by the electricity imports. The driest years include in the analysis was 2005. Hydro power production accounted for only $17 \%$ of the total electricity consumption, but the growth of wind power production partially compensated this lost in renewable production and the thermal power share although high was smaller than in 1999 or 2002. On the opposite, in 2003 the thermal power production share was only 57\% and the electricity production from RES represented 37\%, taking advantage of that year wet regime. 
For the following years, the large hydro sector will maintain a dominant position. However, the wind power sector is expected to gain increasing importance. Between 1997 and 2005, the electricity production from wind presented a significant growth, departing from a $0.2 \%$ share of RES in 1997 to more than $20 \%$ in 2005 . In order to accomplish the targets indicated by the Directive 2001/77/EC national targets were established, for the renewable energy sector for 2010, presented in table 2.

Table 2- National targets for the renewable energy sector. Source: DGGE (2005a), Resolution of the Ministries 63/2003.

\begin{tabular}{lcc}
\hline Renewable source & 2005 (MW) & 2010 (MW) \\
\hline Wind & 980 & 3,750 \\
Small hydro ( $\leq 10 \mathrm{MW})$ & 267 & 400 \\
Large hydro $(>10 \mathrm{MW})_{\text {Biomass }^{1}}$ & 4,476 & 5,000 \\
Photovoltaic & 464 & 330 \\
Tide & 2 & 150 \\
Total & $\mathbf{6 , 1 8 9}$ & 50 \\
${ }^{1}$ Includes cogeneration, urban solid waste and biogas.
\end{tabular}

If REN (2005b) projections are attained, in 2011, the wind power sector will occupy the second place in terms of installed RES power and the third place in terms of total installed power in Portugal, reaching a value close to hydro power. In November 2004, the government released a new program for the reduction of the Portuguese oil dependence ${ }^{4}$. This document pointed the possibility of raising the National wind power above 3,750 MW and anticipating the process. A report published by the BCG (2005) indicates that the concretization of the National targets for large hydro may be difficult to achieve, due to the severe environmental obstacles. This way, in order to fulfil the EU Directive, the installed wind capacity should ascend to 4,750 MW.

\footnotetext{
${ }^{4}$ Programa de actuação para reduzir a dependência de Portugal face ao petróleo, November 2004.
} 


\section{Overview of the RES legal framework}

In 1981, Decree-Law 20/81 recognised the need to reduce the oil dependence of Portugal and the need to give better use to the National energetic resources. This legal text referred the possibility of electricity auto-production, for entities accessorily producing electricity from renewable energy sources or using technologies that would lead to the reduction of primary energy consumption. In 1986, Decree-Law 149/86 enlarged this concept to plants exclusively producing electricity.

In 1988, Decree-Law 189/88 recognised that a quicker process was needed as well as the creation of conditions allowing the small plants' economic viability. With the publication of this legal text, private and public companies were allowed to produce electricity in plants with the maximum installed power of $10 \mathrm{MW}$ using renewable energy sources. The tariffs to be paid to the electricity producer were based on the tariffs charged to the final consumers, and the producer was given a State Guarantee concerning the receipts during the first eight years of the investment amortization. An authorisation procedure was adopted for the construction of new generating plants.

With the aim of adjusting the previous legislation to the bases of the National Electricity System, Decree-Law 313/95 was published in 1995. The installed power limit for the power plants producing electricity from renewable energy sources was abolished, except for the large hydro which remained limited to $10 \mathrm{MW}$ of installed power. This Decree-Law set new rules for the tariffs to be paid to the producers based on the tariffs paid by the final consumers and on the total avoided costs, and it also changed the rules for calculating of the State Guarantee. 
The creation of the internal electricity market in the EU and the ratification of the Kyoto Protocol led to the revision of the legal framework applied to the renewable energy sector. In 1999, Decree-Law 168/99 operated a revision on the tariffs paid to electricity producers from renewable energy sources, and altered the regulation in order to assure fair and transparent treatment of the procedures. The value of the remuneration started to be based on avoided costs and avoided emissions. This legal text set the obligation of the public grid to buy the energy from producers, during the licence period and set the value of the remuneration paid to the producers during the first 144 months of operation of the renewable plant. After this period, the value of the remuneration will decrease due to a reduction on the predicted environmental component of the calculation formula.

Decree-Law 339-C/2001 established differentiated remuneration for each renewable technology and according to the exploration regime. It also assumes that these plants environmental contribution is permanent, thus no temporal limitation is set. Finally, this legal text stipulates the payment of a rental fee by wind power producers to the municipal entities. In the same year, Decree-Law 312/2001 sets the rules for the attribution of reception points, connecting the promoters to the grid. The process is based on an authorisation procedure but it also ruled the possibility of a tendering procedure for the accomplishment of National and European objectives or for the optimisation of the Public grid.

In 2005, Decree-Law 33-A/2005 refers the importance of the increasing of renewable power production, but it also points that the promotion measures may not be blind to the 
energetic bill supported by the consumers. This way, it establishes a new regulatory regime and sets a temporal limitation for these remunerations for each renewable technology, in order to assure the return of the investment made by the promoters. After this time limit, the renewable power plants will be remunerated at market prices and by the sale of green certificates.

Figure 4 presents a summary of the evolution of the legal framework of the renewable energy sector, resuming the main changes of the state guarantee and tariffs paid to wind power producers.

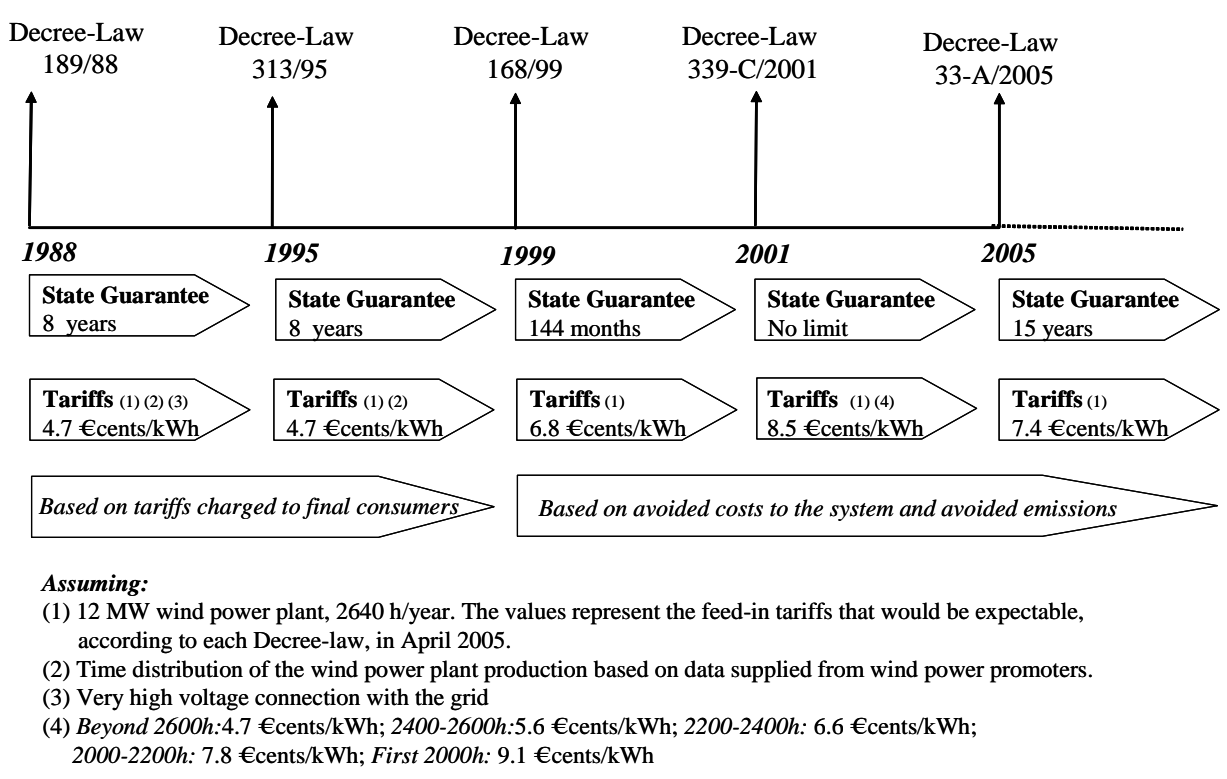

Figure 4- Evolution of the Portuguese legal framework on renewable energies.

The interest of private companies in the wind sector is high and, since the publication of Decree-Law 312/2001, there have been a high number of promoters presenting advanced information requests, reaching 7,000 MW in the first trimester of 2002 (BCG, 2004). This initial response of the promoters exceeded the government expectations and, after this, DGGE conditioned the acceptance of these requests. From May 2002 the 
acceptance of new requests for wind power plants was suspended. Until the end of 2005, DGGE attributed 2,452 MW to wind power promoters (DGGE, 2005a).

In July 2005, the Government launched a tendering procedure for the attribution of new 1,500 MW capacity for wind power producers. The evaluation of the proposals will consider economical and social criteria along with the technical management capacity of the promoter (DGGE, 2005c). The economical criterion is mostly associated with the acceptance of a discount on the tariff presently paid to the wind power producers. The social criteria evaluate the contribution of each contestant to the creation of an economical cluster for the wind power sector in Portugal and to the economical support of National Research \& Development (R\&D) scientific units. The tendering procedure defines the available reception points and the available power injection capacity for each zone of the grid, according to the future evolution of the National grid.

\section{The wind power sector in Portugal}

Figure 5 presents the evolution of the annual and accumulated installed wind power, in Portugal (including islands) between 1995 and 2005. It also indicates the capacity under construction in September 2005. 


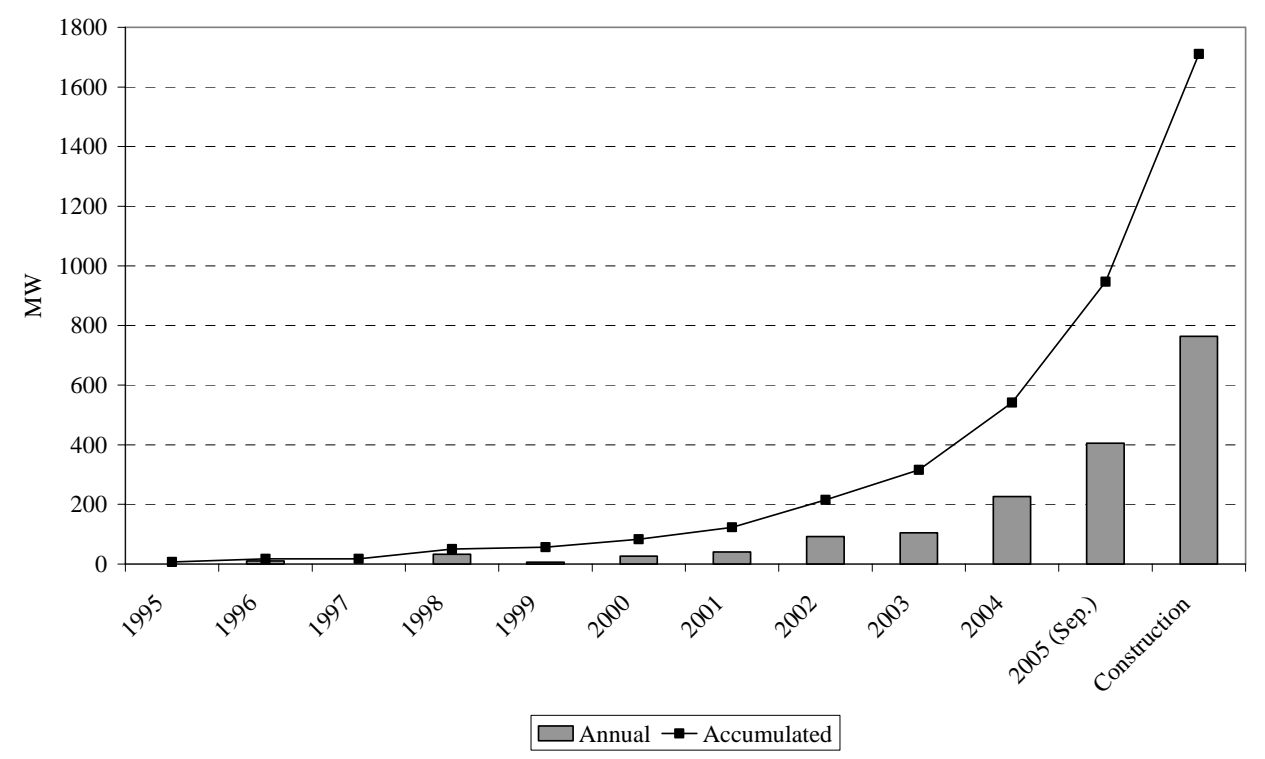

Figure 5- Installed wind power in Portugal, 1995-2005. Source: Own elaboration from DGGE (2005b) and INEGI (2005)

During these years, the installed wind power grew at an average annual rate of $70 \%$, equivalent to nearly $95 \mathrm{MW}$ per year. This growth was especially noticeable in the late years (after 2000), reaching more than $400 \mathrm{MW}$ in 2005. According to INEGI (2005) data, the total installed power was about 950 MW in September 2005. During the next years, this growing trend should continue, due to the remaining $764 \mathrm{MW}$ already under construction or adjudicated to the promoters. Taking into consideration the already licensed power and the additional capacity recently released by the tendering procedure, the perspectives are that the total installed wind power may reach values higher than 4,500 MW in 2010 (REN, 2005b).

The wind power sector is mostly present in the North region of Portugal and the future prospects point to the reinforcement of this situation, as it may be seen from Figure 6. 
Mostly of the wind potential is located in inland hill regions with low consumptions and with underdeveloped electricity grids. There is an excess of inland production that must be transported to the big electricity consumption centres, which implies the reinforcement of the national transmission grid (REN, 2005b).

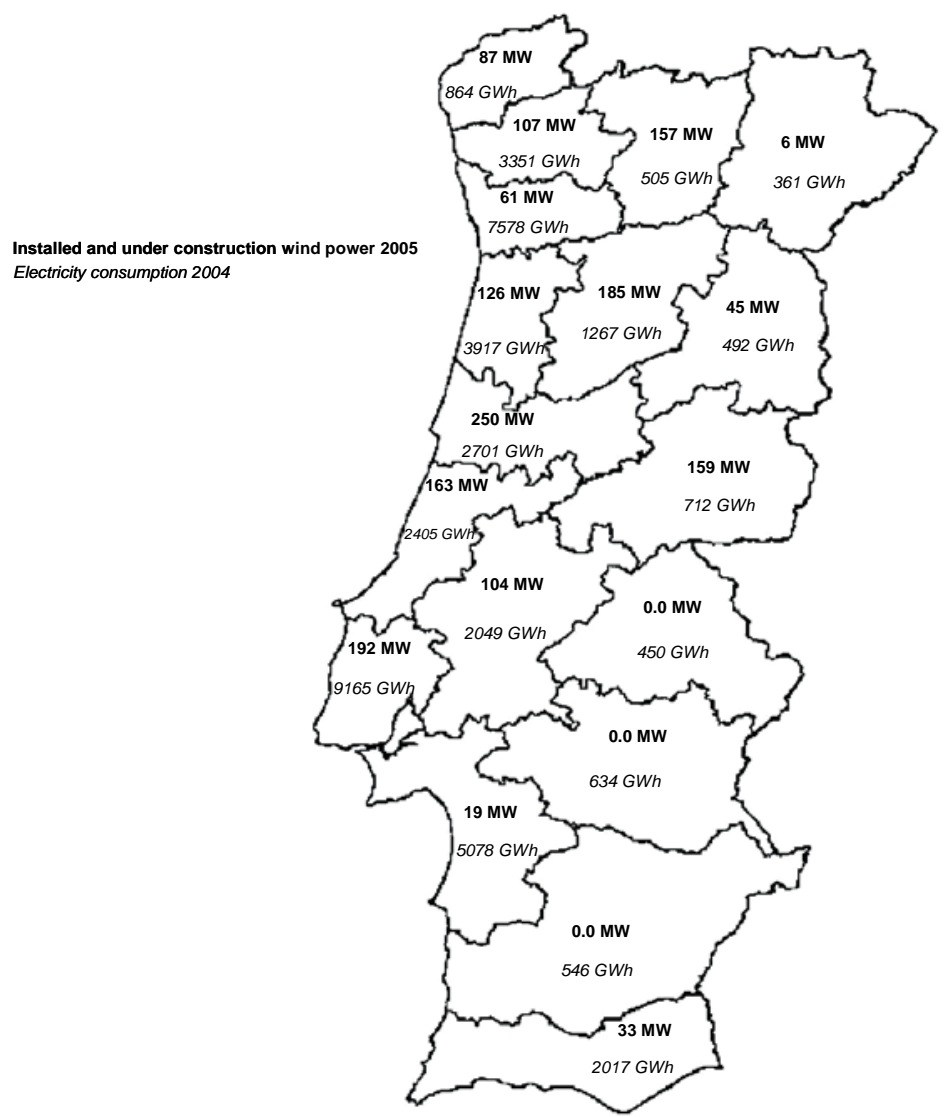

Figure 6- Installed wind power in Portugal (excluding islands). Sources: INEGI (2005) and DGGE site.

The question of the access to the grid was also raised by the BCG (2004) report. This study refers the need to optimize the interconnection of the wind power plants to the grid, historically planed as a centralized system. This report points the difficulties on accessing the grid as one of the major obstacles to wind power development, along with the delays on the licensing procedure (especially associated with the environmental approval) and the uncertainty on the tariff. However, it also recognizes that the sector development was not damaged by low tariffs. 
The same way the European Commission (Commission of the European Communities, 2004) considered that Portugal along with Greece were not on track to achieve the national targets and, identifies the administrative and grid barriers as important problems for the RES development in Portugal.

Decree-Law 3339-C/2001 and previous ones established tariffs for every RES plants already in operation or construction. BGC (2004) stated there were no guarantees on the tariffs for the wind power plants still in project and waiting for approval. However, since February 2005, Decree-Law 33-A/2005, ensures that the tariffs established by this legal text are guaranteed to all the wind power promoters obtaining the operation licence during the two years following the establishment licence. A deadline for the promoters obtaining the establishment licence is also stated, in order to avoid maintaining unjustified reserve capacities of the grid.

As for the administrative barriers and for the delays on accessing the grid, this DecreeLaw does not change the previous situation. It is not imposed any dead line for the construction or improvement of the grids, in order to accelerate the connection process. The same way, it does not the address the problem of the long environmental licensing process.

In 2011, the total installed wind power will represent about $40 \%$ of the annual forecasted peak demand and $12 \%$ of the gross electricity consumption on Mainland ${ }^{5}$. When comparing these values with the three European leading countries in wind power capacity, it is clear that this represents an ambitious goal. In fact, the Danish wind

\footnotetext{
${ }^{5}$ Own calculations based on REN (2005) and assuming an average 20\% load factor for wind power plants.
} 
power production represented in 2004 about $18 \%$ of the total electricity consumption, in Spain this value was $6 \%$ and in Germany $4 \%^{6}$.

However, these countries possess strong interconnected electrical systems with at least three neighbour countries, which may be crucial for the security of supply. See the example of Denmark whose import capacity in the 2004/2005 winter represented about $24 \%$ of its total capacity. Portugal is interconnected only with Spain and, in the 2005/2006 winter, its import capacity represented only slightly more than $7 \%$ of its total capacity $^{7}$. In addition, Germany and Spain are backed up by strong thermal, nuclear and hydropower systems, maintaining this way high reserve margins. In 2004, the reserve margin was 69\% in German and $84 \%$ in Spain ${ }^{8}$.

The large penetration of wind power in Germany influences significantly the power balance of the public electricity supply. The Association of German electricity network operators (VDN, 2005) states that the non-usable capacity (capacity which cannot be freely deployed) of the system, “(...) increases distinctly from year to year, mainly due to the fact that a large part of newly constructed wind generating capacity is considered to be not usable as a result of unsteady availability of wind.”. The same way, the ESB (2004) study for Ireland concludes that the capacity credit for wind power (conventional capacity displaced by wind) raises more slowly with increasing wind shares. This way,

\footnotetext{
${ }^{6}$ Own calculations based on EuroObserv’ER (2005) and Eurostat (2005).

${ }^{7}$ Own calculations based on Danish Energy Authority (2005) and indicative values for Net Transfer Capacities (NTC) published by the European Transmission System Operators (www.etso-net.org).

${ }^{8}$ Own calculations based on REE (2004) and VDN (2005).

Reserve margin $=\frac{\text { Installed power }+ \text { Importation capacity }- \text { Peak demand }}{\text { Peak demand }}$.
} 
the amount of conventional plants that may be replaced by wind plants decreases progressively and tends to zero.

The strengthening of the wind power production in Portugal will imply important changes in the Portuguese electrical system, namely the increase of the power reserve and of the import capacity. It will be necessary to provide the system with the production means capable of compensating the large penetration of intermittent sources.

According to REN (2005b) forecasts between 2005 and 2011 the Portuguese electricity consumptions will grow about 34\% and the peak demand will also grow about 32\%. However, a $41 \%$ increase of the total installed power is predicted, meaning that the reserve margin will grow from the present $61 \%$ to $78 \%{ }^{9}$. This increase results largely from the need to face the increasing uncertainty and intermittency of the output, due to the increasing penetration of wind power in the Portuguese electricity system.

The improvement of interconnection capacity is a key requirement for ensuring the security of supply. The geographical location of Portugal (bordering only to Spain and to the Atlantic Ocean) implies that the Portuguese system may only be interconnected to the European grid through Spain. The European Commission recognizes the need for the electricity network reinforcement in Portugal-Spain, and this project was included among the nine priority axes of the trans-European electricity network in the EU (European Commission, 2004b). The late forecasts (REN, 2005b) indicate that in 2007/2008 the import capacity will achieve 1800 MW, representing almost $10 \%$ of the total capacity of the system.

\footnotetext{
${ }^{9}$ Own calculations based on REN (2005a), REN (2005b).
} 
Additionally, the planning studies of the Portuguese generating system concluded that the use of hydro schemes with reversible capacities to ensure the adequate levels of security of supply is the most appropriate solution. Therefore, it is fundamental to proceed with the planned hydro schemes in order to avoid possible situations of operational reserve deficit (Esteves et al, 2003). At the same time, these hydro schemes represent an important contribution to the fulfilment of the renewable goals established for Portugal. However, the recent REN (2005b) investment plan indicate delays on the construction of new large hydro plants with reversible schemes and considers the possibility of installing regenerative fuel cells in the largest wind power parks.

\section{Towards a wind power planning model}

It is clear that the energy planning is a complex process involving multiple and conflicting objectives and many agents able to influence decisions. The integration of environmental, social and economical issues in the wind power decision making although fundamental is not an easy task and tradeoffs must be made. Zouros et al (2005) point that wind power penetration in an electricity system should be evaluated in terms of security of supply, system economics, environmental impact, technical aspects and impact on the electricity market, taking also into consideration the market conditions.

Different authors and studies use different approaches for solving energy planning problems. These approaches include for example several multicriteria tools, the monetization of all the criteria, the use of a framework for systematic collection and 
analysis of information, the use of strategic planning tools or a combination of two or more of these methods.

Some recent examples of works published in renewable energy planning illustrate the diversity of methods and applications. Cavallaro and Ciraolo (2005), present a multicriteria evaluation of four different energy solutions regarding the installation of wind turbines on an Italian island. The authors used several economical, technical and environmental criteria based on qualitative and quantitative information. Terrados et al (2005), used a SWOT analysis for energy in the development of a strategic plan for a Spanish region. The process was based on an interdisciplinary method and included the participation of the community and experts. Kennedy (2005), developed a methodology for determining the social benefit of wind power valued in monetary terms and applied it to hypothetical scenarios for Long Island, NY. Cormio et al (2004) proposed a single linear programming optimization methodology for energy planning, including renewable energy sources. The objective function consisted in the total cost, including financial costs and life cycle external costs. The model included also environmental constraints for atmospheric pollutants and was applied to an Italian region. Diakoulaki and Karangelis (2005), evaluated four scenarios for the expansion of the Greek electricity system using both multi criteria and cost benefit analysis and considering economical, technical and environmental criteria.

Other studies focus mainly upon financial costs of the wind power. Dale et al (2004), quantified the overall costs arising from large-scale adoption of wind power in UK. The costs included in the analysis were the generation investment cost, fuel costs and network costs. Another study from ESB National Grid (2004), analysed the economic 
implications of large wind power scenarios in the Irish electrical system, quantifying the effect on the thermal power plants and calculated the implicit cost per tonne of $\mathrm{CO}_{2}$ reduction achieved.

The public perception of wind power is also addressed by several authors for a number of countries or regions. The opinions are mostly collected by large sample surveys or using representative groups. Recently, Wolsink (2006) gathered data from several studies and called attention to the need to take into consideration public attitude on wind implementation decisions, not only at a general level but also at the local project level and stressed the importance of including the public in the decision making process. Agterbosch (2005), used a group of entrepreneurs and local civil servants to analyse their perception about the influence of social and institutional conditions in the operational process of realizing wind power projects. The Delphi technique was used by Iniyan and Sumathy (2003) to determine the social acceptance of renewable energy sources in different uses in India. Bergmann et al (2006), used a questionnaire on a sample of the Scottish population to assess the monetary value of positive and negative impacts arising from renewable energy projects. Kaldellis (2005), investigated the public attitude towards wind energy applications using a survey conducted in several Greek territories. The same way, Ek (2005) analysed the attitudes towards wind power among the Swedish electricity consumers as well as the foundations of these attitudes, based on a postal survey.

Further reading on these matters may include Hobbs and Meier (2000) or Løken (2006), that give some examples of multi criteria applications in energy planning and policy. A comprehensive survey of the application of multi criteria decision making to sustainable 
energy may be found on Pohekar and Ramachandran (2004). Greening and Bernow (2004) give some examples describing the use of several multi criteria methods to energy and environmental issues. Also, Jebaraj and Iniyan (2006) present a review of energy models including planning and optimization models among others.

This paper intended to analyse the wind power sector in Portugal, making an overview of the present situation, discussing the main barriers for the exploitation of wind energy, the policies and regulations and the advantages and drawbacks of wind energy. A clear comprehension of all these aspects is fundamental to support the process of developing the wind energy sector based on more defensible decisions. In fact, the design of a planning tool for wind power in Portugal must take into consideration the specific characteristics of the Portuguese electrical system, including the existing and predicted power plants, the evolution of demand for the following years and legal requirements.

The approach to the problem we favour is a combination of different techniques and involves several integrated steps:

- the monetization of the tradable environmental damages (namely $\mathrm{CO}_{2}$ emissions);

- the development of an optimization procedure for detailing plans for new wind plants installation over a planning horizon, including all the criteria capable of being described by mathematical functions;

- the development of a framework for collecting information and value judgments from the agents; 
- and the integration of all the information with multicriteria decision making methods.

\section{Conclusions and final comments}

During the last years, we have been witnessing the development of the wind power sector in Portugal. The Portuguese government considers the reinforcement of this sector as a priority and structural objective for the near future years (Tavares, Martins, 2005). According to the forecasts, in 2011 the wind power generation will represent $12 \%$ of the gross electricity production on Mainland.

The present tariffs and guarantees offered by the State seem to be enough to attract private investors to the wind market. However, Portugal is still much behind the drawn objectives. The problem seems not to be the lack of private promoters or wind potential. The major obstacles to wind power development come from delays on the long licensing procedure along with difficulties on accessing the grid.

The recently released tendering procedure aims to give a new impulse to the sector and, simultaneously, intends to promote a wind power cluster in Portugal. It may contribute significantly to the improvement of the Portuguese RES situation but the 2010 objectives will not be easy to accomplish. The deadline imposed to the promoters to make available the predicted injection power is 2013, and the process is still highly dependent on the licensing procedures and on the expansion of the grid. 
The growth of the wind power share will have a strong impact on all the electricity generating system. The increase, either of the power reserve and of the import capacity, are fundamental means to preserve the security of supply. The large penetration of wind power in Portugal will influence significantly the energy system cost, but it seems also to be essential to materialize the international energetic and environmental commitments. This research will proceed with the proposed multi-perspective evaluation approach adapted for the Portuguese case, based on literature and on participatory methods. The authors expect to provide in the near future a new integrated tool contributing to economical, ecological and social acceptable future energy strategies.

\section{References}

Agterbosch, S., Glasbergen, P. Vermeulen, W., 2005. Social barriers in wind power implementation in The Netherlands: Perceptions of wind power entrepreneurs and local civil servants of institutional and social conditions in realizing wind power projects. Renewable and Sustainable Energy Reviews (in press).

BCG, 2004. O caminho para o desenvolvimento sustentado da PRE em Portugal. September 2004 (In portuguese).

Bergmann, A., Hanley, N., Wright, R., 2006. Valuing the attributes of renewable energy investments. Energy Policy 34, 1004-1014.

Cavallaro, F., Ciraolo, L., 2005. A multicriteria approach to evaluate wind energy plants on an Italian island. Energy Policy 33, 235-244.

Commission of the European Communities, 2004. The share of renewable energy in the EU. COM (2004) 366 final, 26 May 2004.

Cormio, C., Dicorato, Minoia, A., Trovato, M., 2003. A regional energy planning methodology including renewable energy sources and environmental constraints. Renewable and Sustainable Energy Reviews 1, 99-130.

Dale, L. Milborrow, D., Slark, R. Strbac, G., 2004. Total cost estimates for large-scale wind scenarios in UK. Energy Policy 32, 1949-1956.

Danish Energy Authority, 2005. Energy statistics 2004. (www.ens.dk). 
DGGE, 2005a. Energia- estatísticas rápidas de 2004. April 2005. (In Portuguese) (www.dge.pt).

DGGE, 2005b. Renováveis estatísticas rápidas- Dezembro 2005. (In Portuguese) (www.dge.pt).

DGGE, 2005c. Concurso para a atribuição de capacidade de injecção na rede do sistema eléctrico de serviço público e pontos de recepção associados para energia eléctrica produzida em centrais eólicas (In Portuguese) (www.dge.pt).

Diakoulaki, D., Karangelis, F., 2005. Multi-criteria decision analysis and cost-benefit analysis of alternative scenarios for the power generation sector in Greece. Renewable and Sustainable Energy Reviews (in press).

Ek, K., 2005. Public and private attitudes towards "green" electricity: the case of Swedish wind power. Energy Policy 33, 1677-1689.

ESB National Grid, 2004. Impact of wind power generation in Ireland on the operation of conventional plant and the economic implications. February 2004 (www.eirgrid.com).

Esteves, J., Cabral, P., Azevedo, H, 2003. Sustainable evolution of the generating system under large penetration of wind capacity. EWEC- European Wind Energy Conference and Exhibition, Madrid, June 2003.

EuroObserv’ER, 2005. Wind energy barometer. Systèmes Solaires 165, pp. 71-94.

European Commission, 1996. Energy for the future: Renewable sources of Energy Green Paper for a Community strategy. COM(96) 576, November 1996.

European Commission, 1997. Energy for the future: Renewable sources of energy White Paper for a Community strategy and action plan. COM(97) 599, November 1997.

European Commission, 2004a. European energy and transport scenarios on key drivers. Luxembourg , September 2004.

European Commission, 2004b. Tran-European energy networks: TEN-E priority projects. Luxembourg , 10 June 2004.

Eurostat, 2005. Electricity statistics- provisional data for 2004. Statistics in Focus Environment and Energy 5/2005.

EWEA, Greenpeace, 2005. Wind Force 12, a blueprint to achieve 12\% of the world's electricity from wind power by 2020 (www.ewea.org).

Greening, L. A., Bernow, S., 2004. Design of coordinated energy and environmental policies: use of multi-criteria decision making. Energy Policy 32, 721-735. 
Hobbs, B. F., Meier, P., 2000. Energy decisions and the environment. A guide to the use of multicritera methods. Kluwer Academic Publishers, Dordrecht, Netherlands.

INEGI, 2005. Parques eólicos em Portugal- Março 2005.

Iniyan, S., Sumathy, K., 2003. The application of a Delphi technique in the linear programming optimization of future renewable energy options for Índia. Biomass and Bionenergy 24, 39-50.

Jebaraj, S., Iniyan, S., 2006. A review of energy models. Renewable and Sustainable Energy Reviews 10, 281-311.

Kaldellis, J. K., 2005. Social attitude towards wind energy applications in Greece. Energy Policy 33, 595-602.

Kennedy, S., 2005. Wind power planning: assessing long-term costs and benefits. Energy Policy 33, 1661-1675.

Løken, E., 2006. Use of multicriteria decision analysis methods for energy planning problems. Renewable and Sustainable Energy Reviews (in press).

Pohekar, S. D., Ramachandran, M., 2004. Application of multi-criteria decision making to sustainable energy planning- A review. Renewable and Sustainable Energy Reviews 8, 365-381.

REE, 2004. El sistema eléctrico español- avance del informe 2004. 14 December 2004 (in Spanish) (www.ree.es).

REN, 2005a. Dados técnicos 2005 (In Portuguese) (www.ren.pt).

REN, 2005b. Plano de investimentos da rede nacional de transporte 2006-2011 (In Portuguese) (www.ren.pt).

Tavares L., Martins, M, 2005. Programa de investimentos em infra-estruturas prioritárias. 29 June 2005 (In Portuguese).

Terrados, J., Almonacid, G., Hontoria, L., 2005. Regional energy planning through SWOT analysis and strategic planning tools. Impact on renewable development. Renewable and Sustainable Energy Reviews (in press).

VDN, 2005. Facts and figures-Electricity Networks in Germany in 2005. 1 April 2005 (www.vdn-berlin.de).

Wolsink, M., 2006. Wind power implementation: The nature of public attitudes: Equity and fairness instead of 'backyard motive'. Renewable and Sustainable Energy Reviews (in press).

Zouros, N., Contaxis, G. C., Kabouris, J., 2005. Decision support tool to evaluate alternative policies regulating wind integration into autonomous energy systems. Energy Policy 33, 1541-1555. 